\title{
Feral populations of the Australian Red-Claw crayfish (Cherax quadricarinatus von Martens) in water supply catchments of Singapore
}

\author{
Shane T. Ahyong · Darren C. J. Yeo
}

Received: 24 July 2006/ Accepted: 3 January 2007 / Published online: 24 January 2007

(C) Springer Science+Business Media B.V. 2007

\begin{abstract}
The Red-Claw crayfish, Cherax quadricarinatus von Martens, is native to freshwater habitats of northern Australia and Papua New Guinea. Owing to its large size and suitability for aquaculture, C. quadricarinatus has been widely translocated around the world. Unfortunately, $C$. quadricarinatus is also recognised as invasive, having already established feral populations in South Africa, Mexico, Jamaica and Puerto Rico. The hardiness and conspicuous colouration of $C$. quadricarinatus has also made it popular in the aquarium trade worldwide, including Singapore. Here, we report the establishment of feral populations of C. quadricarinatus in the water supply catchments of Singapore.
\end{abstract}

Keywords Cherax quadricarinatus · Freshwater crayfish · Singapore · Feral - Introduction · Invasive $\cdot$ Aquarium trade $\cdot$ Water supply

\section{S. T. Ahyong $(\square)$}

Marine Biodiversity and Biosecurity, National Institute of Water and Atmospheric Research, Private

Bag 14901, Kilbirnie, Wellington, New Zealand

e-mail: s.ahyong@niwa.co.nz

D. C. J. Yeo

Department of Biological Sciences, National University of Singapore, 14 Science Drive 4,

Singapore 117543, Singapore

e-mail: darrenyeo@nus.edu.sg
The Red-Claw crayfish, Cherax quadricarinatus von Martens, is native to freshwater creeks and water bodies in northern Australia and Papua New Guinea (Lawrence and Jones 2002). The RedClaw may reach a total length of about $250 \mathrm{~mm}$ and weigh up to $600 \mathrm{~g}$. The body is conspicuously coloured with red and maroon highlights on a bluegreen to green body. In addition, mature male Red-Claws have a bright red pulvinus on the outer surface of the major chelae, hence the common name. The large adult size, rapid growth rate, tolerance of a wide environmental conditions, simple production technology and suitability for relatively high stocking densities, make $C$. quadricarinatus an ideal candidate for aquaculture (Merrick and Lambert 1991; Lawrence and Jones 2002). Consequently, both within Australia and internationally, C. quadricarinatus has been widely translocated for large-scale aquaculture and the aquarium trade (Doupé et al. 2004; Vigliano and Darrigran 2002; Lawrence and Jones 2002). To date, C. quadricarinatus has been translocated to parts of Africa, Italy, Israel, the continental United States of America, Mexico, the Caribbean, Ecuador, Puerto Rico, Argentina, New Caledonia, China, Taiwan, Japan and Malaysia (see Harlioğlu and Harlioğlu 2006 and references therein). Cherax quadricarinatus is recognised as invasive and has already established feral populations in South Africa, Mexico, Jamaica and Puerto Rico (Williams et al. 2001; Zimmerman 2003; Mendoza 
2004). Here, we report the establishment of feral populations of $C$. quadricarinatus in Singapore.

In the last 6 years, sampling and observations in several water catchment reservoirs in Singapore consistently revealed the presence of $C$. quadricarinatus. Crayfish were sighted and/or collected from at least three of Singapore's major reservoirs, namely Kranji, Lower Peirce and Upper Seletar (Fig. 1) (present study; Timothy Pwee, Leong Tzi Ming and Benjamin Lee, personal communication). Voucher specimens are retained in the Raffles Museum of Biodiversity Research, National University of Singapore. Though large and conspicuously coloured, $C$. quadricarinatus was not recorded by numerous earlier surveys and studies of introduced freshwater species in Singapore (e.g. $\mathrm{Ng}$ et al. 1993; $\mathrm{Ng}$ 1999). Therefore, C. quadricarinatus is likely to be a recent introduction, probably becoming feral sometime between the late 1990s and early 2000s.

Singapore's reservoirs, both inland and coastal, have all been artificially created for use as water supply catchments through the damming of river drainages or river mouths. Though artificial, the forested catchments surrounding several of these reservoirs serve as important refugia for Singa- pore's native freshwater biota. The Central Catchment Nature Reserve (Fig. 1) is the island's largest at around 3,000 ha and is a vital stronghold for Singapore's freshwater biodiversity $(\mathrm{Ng}$ 1999; Ng and Lim 1999; Balke et al. 1999; Yang et al. 1999). It encompasses the forested watersheds of four inland reservoirs (MacRitchie, Upper Peirce, Lower Peirce and Upper Seletar) as well as the only remaining freshwater swamp forest-Nee Soon Swamp Forest. Nee Soon Swamp Forest has extremely high conservation value for Singapore, containing the richest native freshwater fauna and flora on the island $(\mathrm{Ng}$ and Lim 1999). This includes Parathelphusa reticulata $\mathrm{Ng}$, the most vulnerable of three endemic freshwater crab species ( $\mathrm{Ng} 1999)$ and the highest diversity and number of locally rare or threatened water beetles (11 out of 17 species recorded) and semi-aquatic bugs (19 out of 27 species recorded) found on the island (Balke et al. 1999; Yang et al. 1999). Thus, the occurrence of $C$. quadricarinatus in Upper Seletar and Lower Peirce reservoirs is especially alarming because of the proximity of these two reservoirs to Nee Soon Swamp Forest, which lies between and has links to both their drainages.

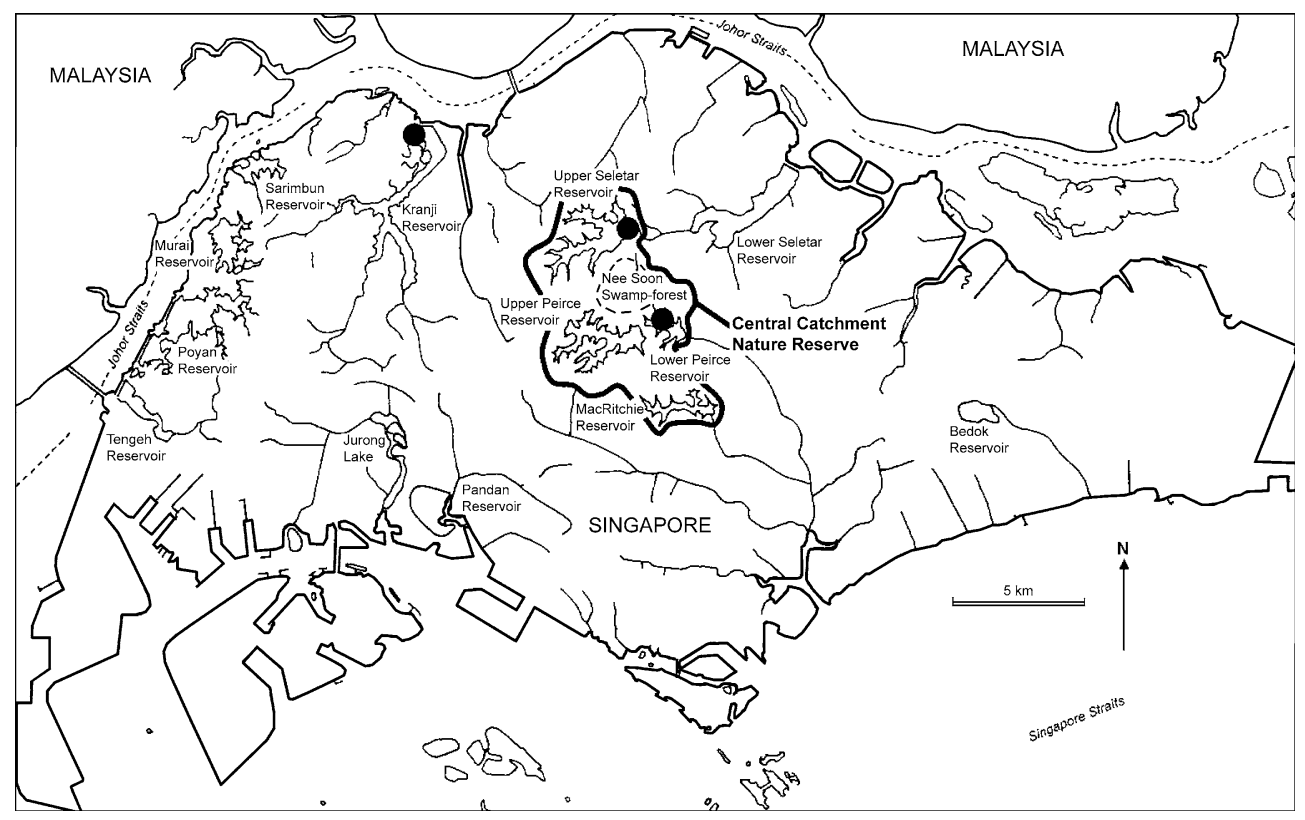

Fig. 1 Map of Singapore indicating water supply catchments and locations where C. quadricarinatus was collected from and/or observed (indicated by filled circle) 
Cherax quadricarinatus is locally abundant. Ovigerous females are yet to be captured by us, but individuals of all sizes and sex, from juveniles to large adults, have been observed indicating that breeding populations are established in Singapore. We are yet to obtain quantitative population estimates, but sufficient numbers of $C$. quadricarinatus are present that they are frequently encountered by casual observers and regularly targeted by recreational fishers and visitors to the reservoirs (Fig. 2). The crayfish are typically caught from near the shore by hook and line, by baited stick, or hand net after individuals are spotted in the open or when otherwise concealed animals are disclosed by their waving antennae (DCJY, personal observation; Timothy Pwee, personal communication).

Trade and culture of aquarium species is a prime source of introduced freshwater species in Singapore (Ng et al. 1993). Cherax quadricarinatus is not presently cultured for human consumption in Singapore, but in the last decade it has become popular in the aquarium trade. As such, Singaporean populations of $C$. quadricarinatus probably derive from accidental or deliberate releases. Of the catchments containing $C$. quadricarinatus, Kranji reservoir is widely separated from Lower Peirce and Upper Seletar reservoirs, being neither connected by aquatic nor terrestrial

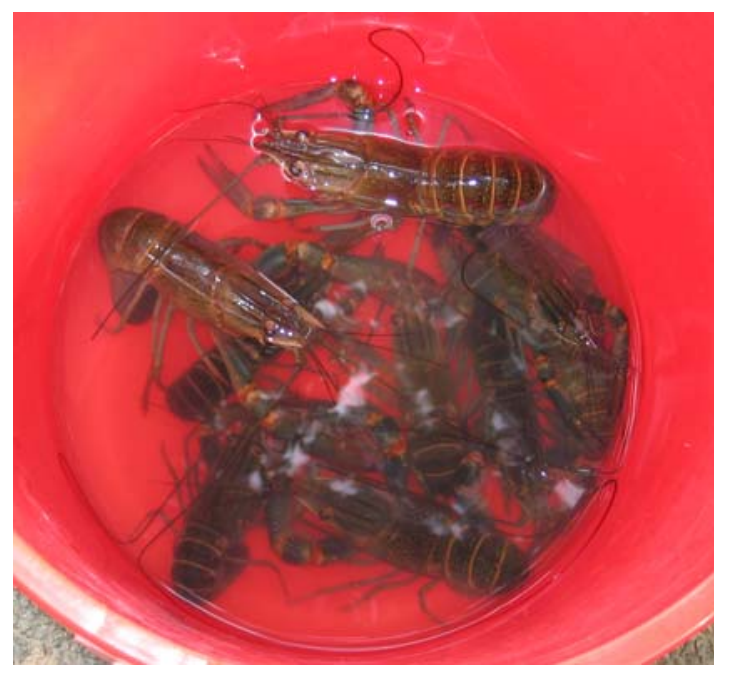

Fig. 2 Red-Claw crayfish (Cherax quadricarinatus Von Martens) captured from Kranji reservoir by recreational fishermen in January 2006 dispersal corridors. Therefore, multiple independent releases or escapes of $C$. quadricarinatus have probably occurred. Other feral species established in Singapore through the aquarium trade include freshwater shrimps [Macrobrachium lanchesteri (de Man) and M. nipponense (de Haan)], freshwater fishes [e.g. the South American loricarid catfish, Liposarcus pardalis (Castlenau) and the Central American guppy Poecilia reticulata Peters) and the North American RedEared Slider (Trachemys scripta elegans (Wied)] (Chou et al. 2006). Other freshwater crayfish species are also common in the Singaporean aquarium trade, though none is yet known from the wild: the American Procambarus clarkii (Girard), the Australian Cherax tenuimanus (Smith) and C. cainii Austin and Ryan and two new species of Cherax originating from Papua New Guinea.

Numerous studies of introduced freshwater crayfish in Europe and North America show that they have negatively impacted species other than native crayfish, such as macrophytes, other macroinvertebrates (especially gastropods), amphibians and fishes (summarised by Lodge et al. 2000; Nyström 2002). Unfortunately, few data are presently available on the dynamics and ecological impact of translocated C. quadricarinatus populations. In the Ord River, Western Australia, where C. quadricarinatus has been recently introduced, the species appears to form a small component of the diet of predatory fish, though its trophic significance remains to be determined (Doupé et al 2004). In Mexico, where C. quadricarinatus is now feral, individuals are known to readily move both up and downstream, and juveniles are reportedly active predators (Mendoza 2004). Like other crayfish, C. quadricarinatus is also a potential disease vector as host to numbers of parasitic or symbiotic microbes and invertebrates. In addition to the fungus Aphanomyces astaci, Rickettsia-like parasites and parvolike virus infections are known from some aquacultured populations (Bowater et al. 2002; Romero and Jimenz 2002). Clearly, in Singapore as with elsewhere, more extensive monitoring is required to assess population size and structure and its environmental impacts. Currently, however, C. quadricarinatus appears to be limited to 
the open-water habitats of the reservoirs proper, which appear to contain relatively few native species ( $\mathrm{Ng}$ et al. 1993). The native freshwater decapod crustaceans, such as the freshwater prawn Macrobrachium platycheles $\mathrm{Ou}$ and $\mathrm{Yeo}$ and the endemic freshwater crabs Johora singaporensis $\mathrm{Ng}$, Irmengardia johnsoni $\mathrm{Ng}$ and Yang and Parathelphusa reticulata, almost exclusively occupy the shaded, acid-water forest streams and swamps of the forested catchments ( $\mathrm{Ng} \mathrm{1999).} \mathrm{As}$ such, C. quadricarinatus would have had little opportunity to impact the strongholds of the native freshwater Crustacea. The reservoirs, however, are connected by drainages to the forest streams and swamps, which provide obvious dispersal corridors. Should C. quadricarinatus invade shaded acid-water forest streams and swamps, the consequences for native decapods could be dire.

Acknowledgments We are grateful to Timothy Pwee, Benjamin Lee and Leong Tzi Ming for sharing their observations of $C$. quadricarinatus in Singapore; Chris Austin for helping to confirm the identity of some museum specimens; and Kelvin Lim for producing the map. Research by STA was supported by Biosecurity New Zealand contract ZBS2005-24.

\section{References}

Balke M, Henrich L, Yang CM (1999) Water beetles (Insecta: Coleoptera) in the nature reserves of Singapore. Proceedings of the Nature Reserves Survey Seminar (1997). Gard Bull Singapore 49(1997): 321-331

Bowater RO, Wingfield M, Fisk A, Condon KML, Reid A, Prior H, Kulpa EC (2002) A parvo-like virus in cultured redclaw crayfish Cherax quadricarinatus from Queensland, Australia. Dis Aquat Organ 50:79-86

Chou LM, Tan HTW, Yeo DCJ (2006) The natural heritage of Singapore. Pearson Prentice Hall, Upper saddle River

Doupé RG, Morgan DL, Gill HS, Rowland AJ (2004) Introduction of redclaw crayfish Cherax quadricarinatus (von Martens) to Lake Kununurra, Ord River, Western Australia: prospects for a 'yabby' in the Kimberley. J R Soc West Aust 87:187-191
Harlioğlu MM, Harlioğlu AG (2006) Threat of non-native crayfish introductions into Turkey: global lessons. Rev Fish Biol Fish 16(2):171-181

Lawrence C, Jones C (2002) Chapter 17. Cherax. In: Holdich DM (ed) Biology of freshwater crayfish. Blackwell, London

Lodge DM, Taylor CA, Holdich DM, Skurdal J (2000) Nonindigenous crayfishes threaten North American freshwater biodiversity: lessons from Europe. Fisheries 25(8):7-20

Mendoza R (2004) Strategies to prevent the spread of invasive aquatic species in Mexico. Paper presented at the Annual Meeting of the Western regional Panel on Aquatic Nuisance Species, La Jolla, 9-11 September 2004

Merrick JR, Lambert CN (1991) The Yabby, Marron and Red Claw: production and marketing. J R Merrick Publications, Artarmon

Ng PKL (1999) The conservation status of freshwater prawns and crabs in Singapore with emphasis on the nature reserves. Gard Bull Singapore 49(1997): 267-272

Ng PKL, Chou LM, Lam TJ (1993) The status and impact of introduced freshwater animals in Singapore. Biol Conserv 64:19-24

Ng PKL, Lim KKP (1999) The diversity and conservation status of fishes in the nature reserves of Singapore. Gard Bull Singapore 49(1997):245-265

Nyström P (2002) Chapter 5. Ecology. In: Holdich DM (ed) Biology of freshwater crayfish. Blackwell, London

Romero X, Jimenez R (2002) Histopathological survey of diseases and pathogens in redclaw crayfish, Cherax quadricarinatus (von Martens), cultured in Ecuador. J Fish Dis 25:653-667

Vigliano PH, Darrigran G (2002) Argentina's freshwater systems: aliens in wonderland. In: Proceedings of the 11th International Conference on Aquatic Invasive Species, Alexandria, 25-28 February 2002

Williams EW Jr, Bunkley-Williams L, Lilyestrom CG, Ortiz-Corps EA (2001) A review of recent introductions of aquatic invertebrates in Puerto Rico and implications for the management of nonindigenous species. Caribb J Sci 37(3-4):246-251

Yang CM, Lua HK, Yeo KL (1999) Semi-aquatic bug (Heteroptera: Gerromorpha) fauna in the nature reserves of Singapore. Gard Bull Singapore 49(1997):313-319

Zimmerman HG (2003) South Africa. In: Mcdonald IAW, Reaser JK, Bright C, Neville LE, Howard GW, Murphy SJ, Preston G (eds) Invasive alien species in southern Africa: national reports and directory of resources. Global Invasive Species Programme, Cape Town 